\title{
MECHANISM OF STARCH BIOSYNTHESIS
}

\author{
By María A. Rongine de Fekete*, L. F. Leloir and C. E. Cardini \\ Instituto de Investigaciones Bioquimicas, Fundación Campomar \\ and Facultud de Ciencias Exactas y Naturales, Obligado 2490 , Buenos Aires, Argentina:
}

Since the classical work of Hanes ${ }^{\mathbb{1}}$ some workers consider that starch synthesis in vivo is catalysed by phosphorylase. Nevertheless, cthers have raised doubts on this hypothesis. Thus Ewart et al. 2, from measurements of the ratio of inorganic phosphate to glucose-1. phosphate, concluded that: "phosphorylase is not involved in the synthesis of starch... but the role of phosphorylase in the normal metabolic breakdown... is not questioned" (cf. also Rowan and Turner ${ }^{3}$ ). Furthermore, Stocking ${ }^{4}$ reported that starch synthesis in leaves is initiated in the chloroplasts, where phosphorylase could not be detected.

The problem of starch synthesis is similar to that of glycogen-synthesis in animal tissues. The synthetic role of phosphorylase in vituo has been challenged on the basis of the following facts: a) the unfavourable ratio of inorganic phosphate to glucose-1-phosphate in tissues; b) agents which increase the concentration of phosphorylase, such as epinephrine and glucagon, produce glycogen breakdown ${ }^{5}$; and (c) in : certain diseases phosphorylase is absent in the muscles, although normal or increased amounts of glycogen are present ${ }^{6}$.

If these facts are sufficient to rule out phosphorylase as the enzyme responsible for glycogen synthesis, the only enzyme which can take its place, so far as we know, is glycogen synthetase ${ }^{7}$, which catalyses the transfer of glucose from uridine diphosphate glucose to glycogen forming a new $\alpha-1: 4$ linkage. On the other hand, it is known that uridine diphosphate glucose acts as glucose donor in plants. Thus enzymes catalysing the synthesis of sucrose $^{8}$, sucrose phosphate ${ }^{9}$, and callose ${ }^{10}$ have been described. The latter is a $\beta-1: 3$ glucan discovered many years ago and believ-

\footnotetext{
* Post-Doctoral Fellow of the University of Buenos Aires.
}

ed to have a role in the physiology of sieve tubes and in wound reaction in plants 12 .

All this suggests that uridine diphosphate glucose should be involved in starch synthesis. Although incubation of radioactive uridine diphosphate glucose with different plant materials usually resulted in the incorporation of radioactivity in the polysaccharide fraction, the product formed was insoluble in hot water, was not hydrolysed by $\beta$-amylase and was presumably callose.

Since glycogen synthetase has been found to be strongly adsorbed on glycogen (ref. $7 c$ ), we have looked for a starch-synthesizing enzyme in starch granules. In preliminary experiments, radioactive uridine diphosphate glucose was incubated with freshly prepared potato starch and it was found that there was some incorporation of radioactivity in the fraction which became soluble by the subsequent action of $\alpha$-amylase. More active preparations were obtained from beans as follows. Freshly harvested immature dwarf string beans (Phaseolus vulgaris var. Bountiful) were used. The cotyledons and the embryos were ground in a mortar with two volumes of water. The suspension was filtered through cheesecloth and centrifuged $5 \mathrm{~min}$. at $3,000 \mathrm{rev}$./ min. The precipitate was resuspended in several volumes of water and recentrifuged three times. The white precipitate was then suspended in four volumes of acetone at - $15{ }^{\circ} \mathrm{C}$. , centrifuged at $09 \mathrm{C}$.; this procedure was repeated three times, after which the precipitate was dried in vacuo. This preparation could be stored for months at $-15^{\circ} \mathrm{C}$. with no decrease in activity.

The bean starch fraction ( $2 \mathrm{mgm}$. containing $6 \mu \mathrm{gm}$. of protein) was incubated at $37^{\circ}$ C. for $3 \mathrm{hr}$. with $0.21 \mu$ mole of uridine diphosphate glucose containing 7,850 counts/ 
min. of carbon-14 in the glucose moiety, 2 $\mu$ moles of glycine buffer of $p H$ 8.4, $0.05 \mu$ mole of ethy.enediamine tetraacetate in a final volume of $15 \mu \mathrm{l}$. After incubation, $0.5 \mathrm{ml}$. of 80 per cent ethanol was added. The soluble fraction was spotted on paper and chromatographed with ethanol-ammonium acetate of $p H$ 7.5 (ref. 15). The uridine diphosphate and uridine diphosphate glucose spots were eluted from the paper and the absorbancy at $260 \mathrm{~m}_{\mu}$, radioactivity and uridine diphosphate were measured. The insoluble fraction was washed with ethanol and counted. Blanks without and with uridine diphosphate glucose added after incubation were run at the same time. Furthermore, it was found that the bean starch fraction did not destroy added uridine diphosphate.
The changes occurring on incubation of the bean starch fraction with radioactive uridine diphosphate glucose are shown in Table 1; these results indicate a correspondence between disappearance of uridine diphosphate glucose, formation of uridine diphospate and incorporation of glucose into the starch fraction.

The identity of the product formed was investigated as follows. The starch fraction after incubation with radioactive uridine diphosphate glucose was thoroughly washed with aqueous ethanol, suspended in water, heated for $10 \mathrm{~min}$. at $1000^{\circ} \mathrm{C}$. and then treated with $\beta$-amylase. Wheat $\beta$ amylase was allowed to act for $12 \mathrm{hr}$. at $37^{\circ} \mathrm{C}$., and 3 volumes of methanol were added. The soluble fraction was evaporated, spotted on paper and

\section{TABLE I}

Analysis of substrates and products

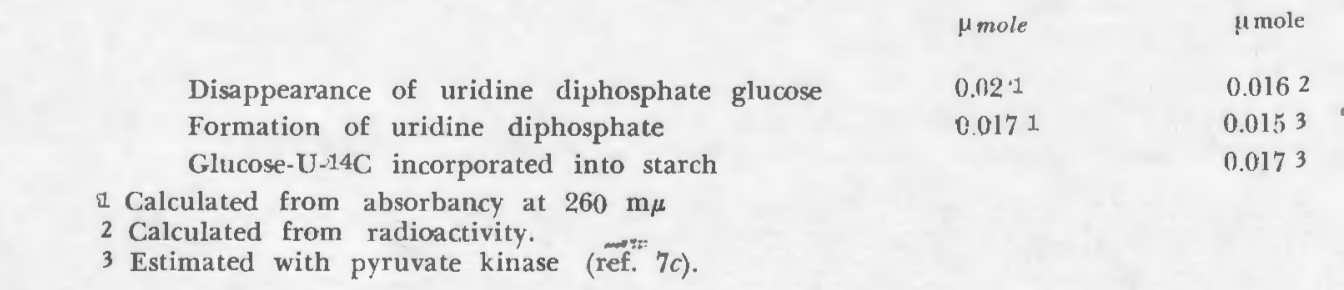
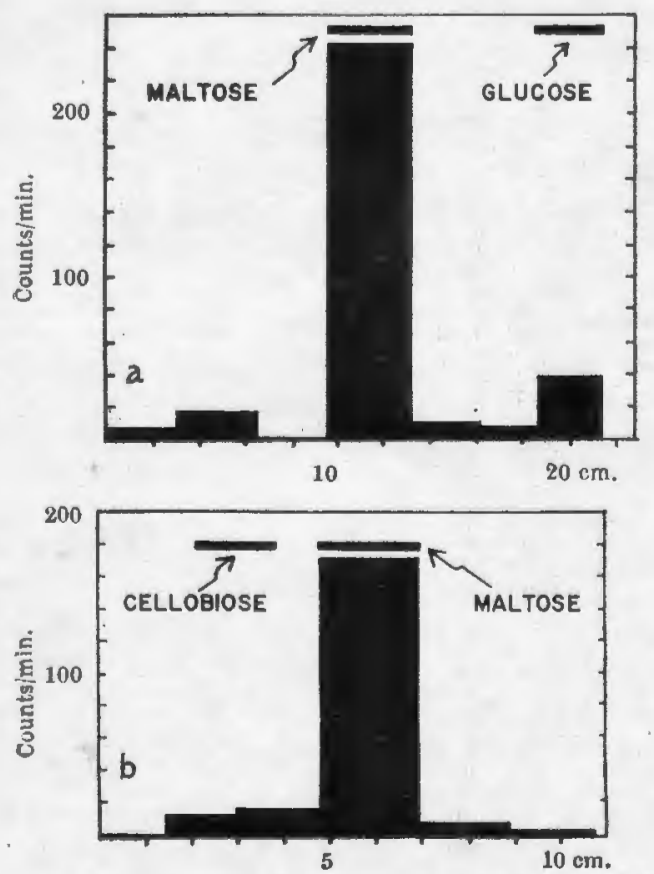

FIG. 1. - (a) Paper chromatography; and (b) paper electrophoresis of reaction product after treatment with $\beta$-amylase. chromatographed with butanol/pyridine/water $(6: 4: 3 \mathrm{v} / \mathrm{v})^{13}$ as solvent. As shown in Fig. l $a$ the radioactivity was found to migrate like maltose. For further confirmation of the identity of the substance, the 'maltose' eluted from the paper after chromatography was submitted to electrophoresis with borate buffer ${ }^{\mathbb{1} 4}$. As shown in Fig. $1 b$, the radioactivity migrated with the 'maltose'. Under these conditions, cellobiose, laminaribiose and gentiobiose are neatly separated from maltose.

\section{TABLE 2}

\section{Donor specificity}

Bean starch fraction (8 mgm.) incubated $1 \mathrm{hr}$. under conditions similar to those indicated in Table I with about 0.2 mole of substrates indicated.

$\begin{array}{lrc}\text { Donor } & \begin{array}{c}\text { Counts/min. } \\ \text { added }\end{array} & \begin{array}{c}\text { Counts } / \mathrm{min} . \\ \text { recovered in } \\ \text { starch fraction }\end{array} \\ \text { Uridine diphosphrate glucose } & 5,300 & 590 \\ \text { Glucose-1-phosphate } & 8,000 & 190 \\ \text { Glucose-6-phosphate } & 10,000 & 210 \\ \text { Sucrose } & 8,500 & 130 \\ \text { Glucose } & 10,000 & 0\end{array}$


Similar results were obtained with $\alpha$-amylase. Saliva (0.1 volume) was allowed to act for $30 \mathrm{~min}$. at $37^{\circ} \mathrm{C}$. and the samples processed as described for $\beta_{\text {ramylase. The results }}$ were similar except that radioactivity appeared also in the maltotriose spot.

These results are consistent with the following formulation:

uridine diphosphate glucose + acceptor $\rightarrow$ uridine diphospbate $+\alpha$-glucosyl-1,4-acceptor

in which the acceptor is starch.

Other experiments were carried out in order to study the specificity of uridine diphosphate glucose as glucose donor. As shown in Table 2, glucose phosphates and sucrose showed some incorporation of radioactivity but much less than uridine diphosphate glucose.

1. Hanes, C. S., Proc. Roy. Soc., B, 128, 421 (1939). -

2. Ewart, M. H., Siminovitch, D., And Brigg, D. R., Plant Physiol., 29, 407 (1954).

3. Rowan, K. S., And Turner, D. H., Aust. J. Biol. Sci., 10, 414 (1957).

4. Stocking, C. R., Amer. J. Bot., 39, 283 (1952).

5. Surherland, E. W., Am. N. Y. Acad. Sci., 54, 693 (1951).

6. Larner, J., and Villar-Palasi, C., Froc. $U$. $S$. Nat. Acad. Sci., 45, 1234 (1959). Mommaerts, W. F. H. M., Illingworth, B., Pearson, C. M., GuIILORY, R'. J., AND SERAYDARIAN, K., ibid., 45; 791 (1959). Schmid, R., Robbins, P. W., AND TrAut, R. R., ibid., 45, 1236 (1959).

7. (a) Leloir, L. F., And Cardini, C. E., J. Amer. chem. Soc, 79, 6340 (1957) . (b) LELOIR, L. F., Olavarría, J. M., Goldemberg, S. H., AND Carminatti, H., Arch. Biochem. Biophys., 81, $508(1959)$. (c) LELOIR, L. F., AND GOLDEMBERG, S. H., J. Biol. Chem., 235, 919 (1960).
Sucrose has been tested as glucose donor in other experiments with various plant tissue preparations with negative results. The - well-known ready conversion of sucrose into starch in vivo might take place indirectly with uridine diphosphate glucose as an intermediate. The formation of uridine diphosphate glucose from sucrose has been detected (refs. $8,9)$ and may be written as follows:

sucrose + uridine diphosphate $\rightleftharpoons$ uridine diphosphate glucose + fructose

The addition of reactions (1) and (2) would result in the formation of starch from sucrose.

This investigation.was supported in part by a research grant (No G-3442) from the National Institutes of Health, U.S. Public Health Service and by the Consejo Nacional de Investigaciones Científicas y Técnicas.

8. Cardini, C. E., Leloir, L. F., and Chiriboga, J., J. Biol. Chem., 214, 149 (1955).

9. Leloor, L. F., and Cardini, C. E., J. Biol. Chem., 214, $157(1955)$.

10. Feingoid, D. S. Neufeid, E. F., and Hassid, W. Z., J. Biol. Chem., 233, 783 (1958).

11. Aspinal., G. O., And Krssler, G., Chem. and Indust, 1296 (1957), Kessler,.G., Ber. schweiz. bot. Ges., 68, 5 (1958).

12. Currier, H. B., And Strugger, S., Protoplasma, 45, 552 (1956).

13. Jeanes, A., Wise, C. S., and Dimler, R. J., Anal. Chem., 23, 415 (1951).

14. Consden, R., And Stanier, W. M., Nature, 169; 783 (1952).

15. Pai.Auini, A. C., And Lelork, L. F., Biochem. J. 51, 426 (1952). 